\title{
KEBIJAKAN PENDIDIKAN DAN PENINGKATAN MUTU PENDIDIKAN
}

\author{
M. Dachnel Kamars
}

\begin{abstract}
This reading regarding the two essential issues nowadays namely: educational policy dan the improving of educational quality. without good and suitable policy ineducation, the quality will be lower and lower and the consequencies are unemployment, property and bribing on the sertificates of each level of education. Because education is so important to increase the property of every one over the world, that is why every country made policies to make education more and more better. Indonesia should fight to increase its position in the human development index among asian and pacific countries, so willd be number less than 112 among 167 countries.
\end{abstract}

Keywords: education, educational quality and policy.

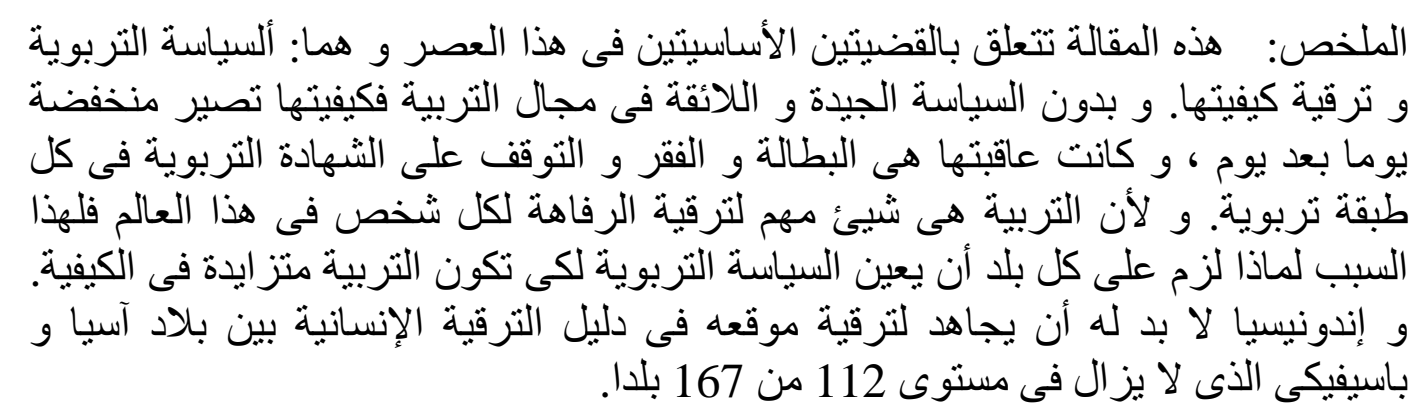

\section{Pendahuluan}

Berbagai upaya telah banyak dilakukan oleh berbagai pihak dalam rangka meningkatkan mutu pendidikan baik pada tingkat sekolah, masyarakat, wilayah (kecamatan, kabupaten/kota maupun propinsi) bahkan oleh negara yang sadar akan arti pendidikan bagi setiap pribadi, masyarakat dan bangsa itu sendiri.

Kesadaran akan arti pendidikan ini ikut menentukan apakah seseorang atau kelompok bahkan suatu bangsa akan dapat memanfaatkan pendidikan untuk meningkatkan harkat dan martabat masing-masingnya. Menurut Steve Barlett dkk (2002) tujuan-tujuan pendidikan secara luas telah disetujui sebagai pengembangan pikiran ,menanamkan pengetahuan yang signifikan, menjamin berlangsungnya secara terus menerus ketertiban masyarakat dan menpersiapkan orang-orang muda untuk menduduki perkerjaan masa depan. Kalau tujuantujuan pendidikan seperti itu telah disadari oleh masyarakat maka besar kemungkinan masyarakat akan memberikan perhatian yang cukup tinggi terhadap pendidikan. Setiap orang akan mau mendukung upaya-upaya pendidikan melalui bantuan pikiran, dana dan tenaga. Untuk mencapai kesadaran yang cukup tinggi akan memakan waktu yang cukup lama. Mungkin puluhan tahun bahkan bisa mencapai ratusan tahun. Ada negara yang telah mencapia kemerdekaannya 50 tahun lalu tetapi sampai tahun ini belum memiliki kesadaran yang memadai terhadap pendidikan sehingga mutu dan relevansi 
pendidikan belum memadai. Sebaliknya ada negara yang dalam waktu belum mencapai 50 tahun merdeka telah mampu mencapai tingkat kesadaran yang memadai sehingga mutu dan revelevansi pendidikannya telah dapat meningkatkan kesejahteraan warganya.

Steve Barlett juga mengutip definisi pendidikan yang dikemukakan Kelly (1999) yang bernuansa politik dengan sarannya sebagai berikut; "Education is a Political activity where by society prepares it's young for adult life. Education and politics are inextricably interwoven and it is not possible to discuss education without considering the political enviroment". Terjemahan bebasnya ialah bahwa pendidikan adalah suatu kegiatan politik di mana masyarakt mempersiapkan orang-orang muda menjadi orang dewasa. Pendidikan dan politik itu tak dilepaskan keterkaitannya dan tidak mungkin membicarakan pendidikan tanpa memperhatikan lingkungan

Jelas bahwa peranan politik terhadap pendidikan dan juga peranan pendidikan terhadap politik merupakan dua pokok pembahasan yang perlu kita lakukan agar semua pihak dapat mengetahui apa peranan masing-masing dalam rangka meningkatkan mutu pendidikan secara umum.

Sebuah informasi baru yang perlu diikuti oleh 191 negara anggota Perserikatan Bangsa-bangsa (PBB) ialah deklarasi Millennium Development Goals (MDGs) atau Tujuan-tujuan Pembangunan Abad Milenium yang harus dicapai pada tahun 2015. Dari delapan target yang harus dicapai tiga yang penulis anggap sangat penting diperhatikan: 1. Meniadakan kemiskinan dan kelaparan ekstrim, 2. Mencapai pendidikan dasar secara universal dan 3. Mengurangi tingkat kematian anak. Tiga target (sasaran) tersebut di atas sangat erat kaitannya dengan kebijakan pemerintah tentang pendidikan yang mengarah ke peningkatan mutu pendidikan yang dapat diterapkan untuk mengurangi tingkat kemiskinan dan mengurangi tingkat kematian anak.

\section{Kebijakan Pendidikan}

Istilah Kebijakan (Policy) dikemukakan oleh Fred M. Frohock dalam bukunya Public Policy (1979), policy is in its most general sense, the pattern of action that resolves conflicting claims or provide incentive for cooperation.

Within the broad term policy, two features stand out. First policy is a social practice, not a singular or isolated event. Second Policy occasioned by the need either to reconcile conflicting claims or to establishe incentive for collective action among those who do share goals but find it irrational to cooperate with one another. Maksudnya kebijakan dalam arti yang umum adalah pola kerja menyelesaikan tuntutan-tuntutan konflik atau benturan atau mampersiapkan insentif (tunjangan-tunjangan) untuk bekerjasama...... Dalam arti kebijakan yang luas, pertama, kebijakan suatu praktek sosial/masyarakat, tindakan suatu peristiwa atau kejadian yang tersendiri atau terisolasi. Kedua, kebijakan adalah saat atau keadaan yang dibutuhkan baik untuk mendamaikan tuntutan-tuntutan konflik atau untuk memantapkan tunjangan-tunjangan (insentif) untuk kegiatan bersama di antara yang ikut punya saham dalam tujuan-tujuan tetapi tidak masuk akal untuk bekerjasama satu dengan yang lain. 
Selanjutnya menurut Plumbo yang dikutip oleh Linconln (1985): Policy refers. To the general intentions or principles that guide specific actions such as a programs and may only be inferred from specific legislative acts, statutes, programs, or court decisions. Policy is not implemented: it is the statuta or program that are implemented. Secara ringkas dapat diartikan kebijakan menyangkut kehendak-kehendak atau prinsip-prinsip umum yang mengarah ke kegiatan-kegiatan khusus seperti sebuah program (kumpulan kegiatan) dan hanya boleh menarik kesimpulan dari tindakan-tindakan khusus legislatif (badan perwakilan rakyat atau pembuatan peraturan), atau status dan program yang dilaksanakan.

Secara umum dapat dikatakan bahwa kebijakan itu merupakan prioritas atas beberapa kemungkinan tindakan, tetapi dipilih tindakan tertentu berdasarkan berbagai pertimbangan. Hal ini sering kita lihat dari kebijakan suatu organisasi seperti pemerintah, lembaga pendidikan atau perusahaan yang memiliki kebijakan tertentu agar diperoleh hasil yang optimal.

Kebijakan pendidikan maksudnya menyangkut hal-hal apa dalam pendidikan yang perlu diprioritaskan. Jika pemerintah umpamanya memilih kebijakan yang kurang pas, maka ada kemungkinan mutu pendidikan tidak mencapai tingkat yang menguntungkan peserta didik atau warga negara secara keseluruhan. Contohnya, kalau kebijakan pemerintah hanya menyediakan dana pendidikan jauh di bawah $20 \%$ dari APBN, maka mutu pendidikan yang dihasilkan juga akan jauh dari harapan semua pihak. Bahkan akan terjadi pembodohan atau memiliki pengetahuan, keterampilan dan kemauan/kesungguhan dalam mengisi lapangan kerja. Akibat gaji dosen dan guru yang rendah maka kompetensi dosen dan guru tidak dapat memenuhi persyaratan yang umum berlaku dalam dunia pendidikan ada negara-negara maju (developed countries), system penggajian pegawai negeri diatur sesuai dengan keperluan hidup pegawai. Artinya di samping untuk biaya hidup seharihari juga perlu diperhatikan keperluan berobat dan masa pensiun, sehingga sewaktu menjadi pegawai telah berusaha menabung/menyimpan (saving). Keadaan di negara-negara berkembang (developing countries) kesejahteraan pegawai kurang diperhatikan oleh pemerintah sehingga mutu pendidikan tertinggal. Ijazah yang diperoleh tidak menjamin kemampuan pemegangnya untuk dapat melanjutkan ke jenjang yang lebih tinggi dan juga tidak dipersiapkan untuk memasuki dunia kerja. Artinya bukanlah suatu yang menjanjikan bagi para lulusan suatu program sesuai dengan harapan peserta didik. Keadaan yang paling parah adalah pada negara-negara yang sangat tidak berkembang (least developed countries). Sistem penggajian di negara-negara ini sangat jauh di bawah kebutuhan minimal para pegawai. Akibatnya sangat bermacam-macam, mulai dari kemampuan guru dan dosen sangat rendah, kurang gizi, mengajar kurang bersemangat serta tidak memiliki masa depan sesudah pensiun. Penderitaan demi penderitaan saling bersambung, bagi guru dan dosen. Akibatnya para lulusan suatu program pendidikan kadang-kadang merupakan mala petaka. Permainan angka lulusan mulai dari jenjang sekolah dasar sampai jenjang perguruan tinggi telah wajar terjadi. Kualitas lulusan sekolah dasar sampai perguruan tinggi merosot sehingga Ujian Nasional yang 
dilakukan pemerintah banyak diragukan kesahihannya karena terlalu banyak pihak yang tidak bekerja sesuai dengan prinsip-prinsip evaluasi yang murni.

Kebijakan pendidikan di negara-negara berkembang dan sangat tidak maju sangat mengkhawatirkan, bahkan ijazah atau gelar sudah sering diperjual belikan mulai dari tingkat SD sampai ke gelar Doktor dan Profesor. Sebaliknya di negara-negara maju sistem pendidikannya makin canggih dengan mutu Internasional. Oleh sebab itu kebijakan pendidikan nasional haruslah dikaji ulang tiap tahun atau paling lambat lima tahun untuk memperbaiki mutu pendidikan yang dapat mempersiapkan generasi muda menjadi generasi penerus yang makin bertanggung jawab atas kesejahteraan warga negara. Hal ini menyangkut semua unsur atau komponen dalam sitem pendidikan nasional, mulai dari guru, siswa, kurikulum, manajemen, dana, sarana dan partisipasi masyarakat terhadap kelancaran lembaga pendidikan dan mutunya. Tanpa koreksi atas kebijakan pendidikan yang sesuai dengan keperluan zaman maka mutu pendidikan bisa berjalan di tempat atau akan selalu menepati Human Development Index (HDI) no. 112 dari 167 negara-negara di Asia Fasifik.

\section{Peningkatan Mutu Pendidikan}

Istilah mutu banyak yang belum paham sehingga kurang mendapat perhatian terutama oleh para guru dan dosen. Dalam kalangan perusahaan dan industri tuntutan mutu ini sudah merupakan hidup-mati suatu perusahaan/industri. Secara umum dan singkat dapat disimpulkan bahwa mutu berarti kepuasan pelanggan/pemakai. Jadi suatu pendidikan dikatakan bermutu para lulusan lembaga merasa puas dan keperluannya dapat dipenuhi untuk selanjutnya dapat digunakan baik melanjutkan pendidikan, maupun untuk memperoleh lapangan kerja. Setiap orang tersangkut dengan dua hal itu. Jika ia masih memerlukan melanjutkan pendidikan, maka setelah menyelesaikan satu jenjang, maka ia akan meruskan pada jenjang berikutnya. Terakhir ialah seorang lulusan akan mencari kerja untuk membiayakan kehidupannya. Pertanyaan yang muncul ialah: apakah ijazah yang telah dimilikinya itu dapat digunakannya untuk diterima bekerja atau menciptakan sendiri lapangan kerja. Kalau kedua hal itu tidak terpenuhi maka dapat dikatakan jenjang pendidikan itu tidak bermutu, karena tidak dapat memuaskan pemilik ijazah itu.

Keadaan tragis ini telah menimpa negara-negara yang sangat tidak berkembang paling kurang 10 tahun terakhir. Atas dasar persaingan antar negara yang makin meningkat, maka banyak negara yang berusaha memperbaiki sistem pendidikannya menjadi bermutu. upaya-upaya membuat pendidikan bermutu, maka konsep Manajemen Mutu Keseluruhan (Total Quality Management) banyak diterapkan dalam dunia pendidikan, yang semula telah berhasil diterapkan pada bidang industri dan perusahaan bahkan pada pemerintahan.

Adapun defenisi Manajemen Mutu Keseluruhan di kemukakan oleh Lunerburg dan Ornstein (2000) sebagai berikut: TQM is based on the assumption that people want to do their best and that it is management's job to enable them to do so by constntly improving the sistem in which they work. Artinya TQM (Total Quality Management) di dasarkan atas anggapan bahwa orang-orang mau 
bekerja dengan sebaik-baiknya, yaitu pekerjaan manajemen untuk membuat mereka seperti itu secara terus-menerus memeperbaiki sistem pada tempat mereka bekerja. Defenisi-defenisi lain pada umumnya senada dengan di atas, yang tujuan akhirnya memberikan kepuasan pada pelangan/ pemakai.

Kalau suatu lembaga pendidikan mau meningkatkan mutunya berarti secara keseluruhan harus dilakukan perbaikan (improving) yang terus menerus terhadap semua unsur/komponen dalam lembaga itu, artinya mulai dari kepala, para wakil kepala, para kepala bagian/bidang sampai kepada para pekerja harus diperbaiki melalui latihan, pembelajaran dan pendidikan, begitu juga perguruan tinggi harus memiliki rektor, para pembantu rektor, para dekan, para ketua jurusan serta para dosen dan karyawan haruslah orang-orang terpilih yang akan dapat memuaskan para pelanggan mereka yaitu: mahasiswa, para pemakai lulusan itu seperti industri/perusahaan, kantor-kantor pemerintah dan swasta, bahkan sekolah-sekolah pun harus merasa puas dengan guru-guru yang dihasilkan oleh LPTK-LPTK.

Hasil peningkatan mutu pendidikan dalam bentuk semua unsur yang ada di dalamnya merupakan suatu kebijakan pendidikan yang harus dianut oleh pemerintah, dewan perwakilan rakyat serta perusahaan swasta lainya.

Sebagai contoh, jepang yang kalah perang pada tahun 1945, telah dapat bangkit kembali pada tahun sekitar 1960-an oleh kerena tokoh-tokoh jepang mau mengikuti nasehat juran dan deming yang mendorong mereka ke arah peningkatan mutu terus-menerus.

Semoga bangsa Indonesia terutama pada pemimpinnya mulai dari kelas atau jabatan kecil/rendah sampai kelas besar/tinggi mau melakukan perubahan terus menerus ke arah perbaikan mutu. Insya Allah Indonesia bisa makmur dan adil. 